\title{
Erianinin HT29 Kolorektal Kanser Hücrelerinin Proliferasyonu ve Koloni Oluşumu Üzerine Etkilerinin Araştırılması
}

\author{
Sema SERTER KOÇOĞLU ${ }^{1}$, Levent ELMAS ${ }^{2}$, Mücahit SEÇME ${ }^{3}$ \\ 1 Balıkesir Üniversitesi Tıp Fakültesi, Histoloji ve Embriyoloji Anabilim Dalı, Balıkesir. \\ 2 Bakırçay Üniversitesi Tıp Fakültesi, Tıbbi Biyoloji Anabilim Dalı, İzmir. \\ 3 Pamukkale Üniversitesi Tıp Fakültesi, Tıbbi Biyoloji Anabilim Dalı, Denizli.
}

\section{ÖZET}

Kolorektal kanser, dünyada kanser ilişkili ölümlerin en yaygın dördüncü sebebidir. Erianin antioksidan ve anti-tümör etkilere sahip Dendrobium ekstraktından elde edilen yeni bir dibenzil bileşiğidir. Bu çalışmada, erianinin HT29 kolorektal kanser hücreleri üzerine olan terapötik etkileri araştırılmıştır. Erianinin HT29 hücre canlılığı üzerine etkileri XTT test ile koloni oluşumu üzerine etkileri ise koloni formasyonu ile değerlendirilmiştir. Erianinin HT29 hücrelerinde $\mathrm{IC}_{50}$ değeri 48. saatte $59.05 \mu \mathrm{M}$ olarak belirlenmiştir. HT29 hücre dizisinde erianin uygulanan grupta koloni sayısı $67 \pm 33$ iken kontrol grubunda 350 189 olarak hesaplanmıştır. Erianin, HT29 kolorektal kanser hücrelerinde koloni oluşumunu ise anlamlı derecede azaltmıştır. Yapılan çalışmaların sonuçları, erianinin kolorektal kanser tedavisinde doğal elde edilen bir bileşik olarak güvenli, kolay ulaşılabilir ve umut veren terapötik bir ilaç olabileceğini destekler niteliktedir. Gelecekte erianinin kolorektal kanser hücreleri üzerindeki etki mekanizmasını aydınlatacak daha kapsamlı ve çok merkezli desteklenecek ileri düzeyde klinik çalışmalara ihtiyaç vardır.

Anahtar Kelimeler: Erianin. HT29. Kolorektal kanser.

Investigation of the Effects of Erianin on Proliferation and Colony Formation of HT29 Colorectal Cancer Cells

\begin{abstract}
Colorectal cancer (CRC) is the 4th most common cause of cancer-related death in the global world. Erianin, a novel dibenzyl compound in Dendrobium extract, has antioxidative and antitumor activities. In this study, the therapeutic effects of erianin on HT29 colorectal cancer cells were investigated. Effects of erianin on cell viability were evaluated by XTT test. Effects of erianin on colony formation were evaluated by colony formation analysis. IC ${ }_{50}$ values of Erianin on HT29 cells were determined as $59.05 \mu \mathrm{M}$ at 48th hour. While the number of colonies in the HT29 cell line was $67 \pm 33$ in the erianin treated group, it was calculated as $350 \pm 89$ in the control group. Erianin significantly reduced colony formation in HT29 colorectal cancer cells. The results of the presented studies support that erianin as a natural product in the treatment of colorectal cancer can be a safe, easily accessible and promising therapeutic drug. In the future, more comprehensive and multi-center supported clinical studies are needed to elucidate the mechanism of action of erianin on colorectal cancer cells.
\end{abstract}

Key Words: Erianin. HT29. Colorectal cancer.

Geliş Tarihi: 18.Nisan.2021

Kabul Tarihi: 02.Temmuz.2021

Dr. Sema SERTER KOÇOĞLU

Balıkesir Üniversitesi Tıp Fakültesi

Histoloji ve Embriyoloji Anabilim Dalı,

Balıkesir, Türkiye.

Tel.: 05376659319

E-posta: serter_bio@hotmail.com

Yazarların ORCID ID Bilgisi:

Sema SERTER KOÇOĞLU: 0000-0002-3180-4007

Levent ELMAS: 0000-0002-6865-6466

Mücahit SEÇME: 0000-0002-2084-760X
2018 yılında, Birleşmiş Milletlerde, 145.600 yetişkine kolorektal kanser (KRK) teşhisi konulmuştur ${ }^{1}$. Çevresel ve genetik faktörler, ileri yaş, uzun süreli kronik inflamasyon, kişisel veya ailede kolorektal polip öyküsü, sağlıksız diyetler, obezite ve yaşam tarzı gibi faktörlerin KRK geliştirme olasılığını artırdığı iyi

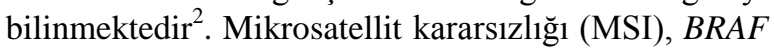
mutasyonları, PIK3CA mutasyonları ve KRAS mutasyonları KRK'nın gelişimi ile yakından ilişkili ana faktörlerdir. Daha yakın zamanlarda, SMAD4 kaybı, kemorezistans ve azalmış immün infiltrasyon ile anlamlı ilişkisi nedeniyle KRK hastaları için umut verici bir prognostik belirteç olarak tanımlanmıştır ${ }^{3}$.

İç organlarda gelişen bir kanser türü olan KRK hızlı bir şekilde invaze olup vücudun diğer organlarına yayılır. Son 5 yılda hayatta kalma oranı $\% 10$ 'un altın- 
dadır ${ }^{1,4}$. Mevcut tedavi yöntemleri hastalığın derecesine bağlı olarak cerrahi ve kemoterapidir ${ }^{5}$. Floropirimidin-bazlı kemoterapi KRK hastaları için uygulanan standart kemoterapi yöntemidir. Kemoterapi ile tümör ilerlemesi durdurulabilir. Ancak, çoğu kemoterapi ajanı vücuttaki normal hücreler için toksik etki gösterir $^{6}$. Genellikle, hastalarda hızlı bir şekilde kemoterapi ilaç direnci ve metastaz gerçekleşir ve teşhisi takiben 5 yıl içinde ölüme neden olur ${ }^{4}$. Hastaların ölümüne kanser hücrelerinin metastazı ve yayılması neden olur. Kolorektal kanserin ana tedavisi cerrahi rezeksiyondur. Son yıllarda, cerrahi sonrası kanserin yayılma riskinin arttığını gösteren çok sayıda çalışma vardır. Tümör damar yaralanması ve cerrahi, tümör hücrelerinin kan dolaşımına girmesine ve tümörün daha hızlı yayılmasına neden olmaktadır ${ }^{7}$. Kolorektal kanserin teşhis ve belirlenmesindeki zorluktan dolayı, KRK hastaları için daha güvenli, uygun maliyetli, daha az risk taşıyan ve hastaların yaşam konforunu arttıracak yeni tedavi ajanlarına ihtiyaç vardır ${ }^{7}$.

Doğal bileşikler, insanlar için kanser araştırmalarında güvenli bir profil çizmeleri ve tedavideki etkinlikleri dolayısıyla yüzyıllardır kullanılmaktadır ${ }^{8}$. Dendrobium, orkidegiller familyasına ait çeşitli biyolojik ve tıbbi özelliklere sahip çok büyük bir yayılım gösteren orkide cinsidir 9 .

Erianin [2-Methoxy-5-(2-(3,4,5-trimethoxyphenyl)ethyl)-phenol], Dendrobium chrysotoxum'dan elde edilen anti-tümör ve antioksidan özelliklerinden dolay1 tercih edilen doğal bir bibenzil bileşiğidir ${ }^{10}$. Erianinin antikarsinojenik özellikleri ve etki mekanizmasına ait çalışmalar sınırlıdır. Servikal kanser ${ }^{11}$, mesane kanser $^{12}$, osteosarkoma ${ }^{13}$, akciğer kanseri $^{14}$, meme kanseri $^{15}$ erianinin antikarsinojen etkilerinin çalışıldı $\breve{g}_{1}$ kanser türleridir. Erianinin HT29 kolorektal hücrelerinin canlılığ 1 ve koloni oluşumu üzerine etkileri daha önce çalışılmamıştır.

$\mathrm{Bu}$ çalışmada, erianinin HT29 hücreleri üzerindeki terapötik etkisi ilk kez çalışılmıştır. Erianinin KRK hücreleri üzerindeki terapötik etkisini göstermek için HT29 KRK hücre dizisi kullanılmıștır. Bu bağlamda bu çalışmada, erianinin HT29 KRK hücrelerinin canl1lığ1 ve koloni oluşumu üzerine etkileri değerlendirilmiştir.

\section{Gereç ve Yöntem}

\section{Hücre Kültürü ve Reaktifler}

Bu çalışmada, HT29 KRK hücre dizisi (ATCC, USA) kullanılmıştır. Hücreler $2 \mathrm{mM}$ L-glutamin, penisilin (20 units $/ \mathrm{mL})$, streptomisin $(20 \mu \mathrm{g} / \mathrm{mL})$ ve $\% 10$ fetal sığır serumu içeren DMEM (Dulbecco's Modified Eagle Medium) kültür ortamında \%95 hava ve \%5 $\mathrm{CO}_{2}$ basıncı altında $37^{\circ} \mathrm{C}$ 'de inkübe edilmiştir. Erianin (Wuhan, China) dimetil sülfoksit (DMSO) içinde çözülmüştür. HT29 hücreleri $2 \mu \mathrm{M}, 4 \mu \mathrm{M}, 8 \mu \mathrm{M}, 16$ $\mu \mathrm{M}, 32 \mu \mathrm{M}, 64 \mu \mathrm{M}, 128 \mu \mathrm{M}$ erianin ile 24,48 ve 72 . saatler için doz ve zaman-bağımlı olarak inkübe edilmiştir.

\section{Hücre Sayımı}

Hücre proliferasyonu deneyleri öncesinde, deneyde kullanılacak hücre sayısını belirlemek için hücre sayımı yapılmıştır. HT29 hücrelerinin sayım işlemi Neubauer sayım lamı kullanılarak, tripan mavisi boyama yöntemine göre uygulanmıştır. Temiz ve steril mikro santrifüj tüpü içerisine $50 \mu \mathrm{l}$ tripan mavisi ve 50 $\mu l$ hücre süspansiyonundan eklenip karıştırılmıştır. Elde edilen karışımdan $10 \mu \mathrm{l}$ alınarak Neubauer hücre sayım lamına aktarılmış invert mikroskopta $10 \mathrm{X}$ büyütmede sayım işlemi gerçekleştirilmiştir. Kesin hücre sayısı, lamın dış kısmında bulunan 4 büyük alandaki toplam hücre sayısının ortalaması alınarak, aşağıdaki formüle göre hesaplanmıştır.

Hücre Konsantrasyonu (hücre/ml) = (Toplam Hücre sayısı / 4) x 10.000 x Dilüsyon Faktörü

\section{Hücre Canlılı̆gl}

Erianinin HT29 hücrelerindeki $\mathrm{IC}_{50}$ dozunun ve hücre canlılı̆̆ının belirlenmesi için XTT (2,3-bis (2methoxy-4 nitro-5- sulfophenyl)-2H-tetrazolium-5carboxanilide) üretici firmanın talimatlarına göre uygulanmıştır. Erianin 96 kuyucuklu plaklara her kuyucukta $1 \times 10^{4}$ hücre olacak şekilde ekilmiştir. 24 saatlik inkübasyon sonrası çeşitli konsantrasyonlarda erianin ile muamele edilmiş ve 24,48 ve 72 saat için inkübasyona bırakılmıştır. Hücre canlılığı değerlendirmek için XTT karışımı üretici firmanın protokolüne uygun olarak hazırlanmıştır. Formazan oluşumu mikroplaka okuyucu kullanılarak ve 630nm dalga boyu referans alınarak spektrofotometrik olarak belirlenmiştir. Hücre canlılığı aşağıdaki formül baz alınarak hesaplanmıştır. Kontrol ve erianin doz grupları her bir plaka için üç tekrarlı olarak çalışılmıştır.

\% Hücre Canlılı̆̆ $=$ Ölçülen optik dansite değeri/Kontrol optik dansite değeri x 100

\section{Koloni Formasyonu Analizi}

Koloni oluşumunu belirlemek için HT29 hücreleri 6 kuyucuklu plakalara her kuyucukta 1000 hücre olacak şekilde ekilmiş ve 24 saat için inkübasyona bırakılmıştır. İnkübasyon sonrası kontrol ve doz grupları oluşturulmuş ve 48 saat inkübe edilmiştir. Besiyeri her 2 günde bir değiștirilerek $37^{\circ} \mathrm{C}$ 'de $\% 5 \mathrm{CO}_{2}$ 'li ortamda 14 gün süreyle inkübasyona bırakılmıştır. Süre sonunda hücrelerin fikse edilmesi için \%10'luk metanol kullanılmış ve $-20^{\circ} \mathrm{C}$ 'de 10 dakika bırakılmıştır. Fikse olan koloniler kristal viyole (\% 0.5 dilution, Merckmilipor, ABD) boyası ile boyanmış ve PBS ile yıkanmıştır. Doz ve kontrol grupları 3 tekrarlı olarak yapılmış ve 1ş1k mikroskobu kullanılarak manuel olarak sayılmıştır ${ }^{16,17}$. 


\section{Erianinin HT29 hücreleri üzerine etkileri}

\section{Istatistiksel Analiz}

Kontrol ve doz grupları arasındaki istatiksel anlamlılık karşılaştırılması 'Student $\mathrm{t}$ test' ile yapılmıştır. İstatiksel analiz değerlendirmesi için SPSS 17.0 istatistik analiz programı kullanılmış ve $\mathrm{p}<0.05$ anlamlı olarak kabul edilmiştir.

\section{Bulgular}

\section{Erianinin HT29 KRK Hücre Canlılı̆̆ını Azaltır}

Erianinin HT29 KRK hücrelerinin canlılığı üzerine etkileri XTT yöntemi ile belirlenmiştir. Erianin, HT29 kolon kanseri hücrelerinde doz ve zaman bağıml olarak hücre canlılığını azaltmıştır. 24'üncü saatte erianin HT29 KRK hücre canlılığını \%50'nin altına düşürdüğü bir doz belirlenememiştir. 48 ve 72 'inci saatte erianinin HT29 hücrelerinin canlılığını \%50'nin altına düşürdüğü doz sırasıyla, 64 ve $16 \mu \mathrm{M}$ olarak belirlenmiştir. Erianinin HT29 kolon kanseri hücrelerinde $\mathrm{IC}_{50}$ dozu 48'inci saatte $59.05 \mu \mathrm{M}$ olarak belirlenmiştir (Şekil 1).

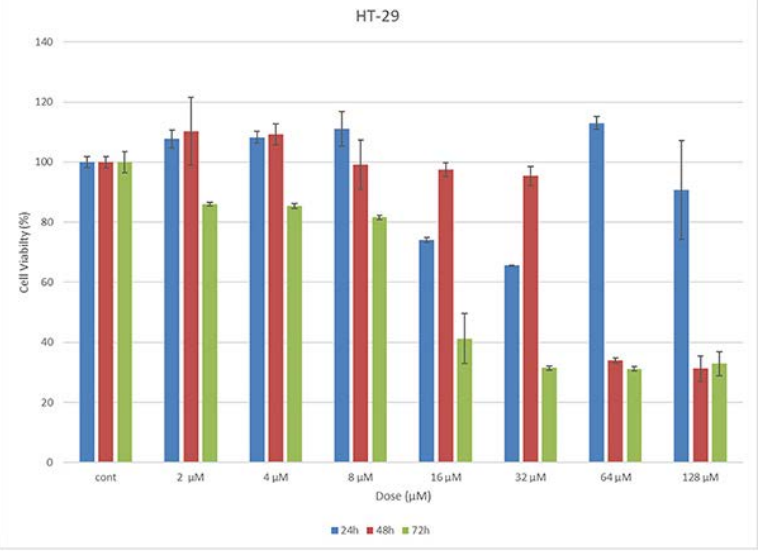

Şekil 1.

Erianinin HT29 KRK hücrelerinde hücre canlılı̆̆ üzerine etkileri. Data 3 bağımsız deneyin ortalama sonuçlarını göstermektedir. Erianinin $I C_{50}$ değeri HT29 hücrelerinde 48 saat için $59.05 \mu$ M olarak bulunmuştur.

\section{Erianin HT29 KRK Hücrelerinde Koloni Formasyo- nunu Azaltır}

Erianinin HT29 KRK hücrelerinde koloni oluşumunu değerlendirmek için koloni formasyonu analizi uygulanmıştır. HT29 hücrelerinde, erianin uygulanan grupta kontrol grubuyla kıyaslandığında, koloni oluşumunun anlamlı olarak azaldığı gösterilmiştir (Şekil 2A). HT29 hücre dizisinde erianin uygulanan grupta koloni sayıs1 $67 \pm 33$ iken kontrol grubunda $350 \pm 89$ olarak hesaplanmıştır (Şekil 2B). HT29 hücrelerinde koloni sonuçları erianin uygulan grupta koloni sayısının \% 80.85 azaldığını göstermiştir.
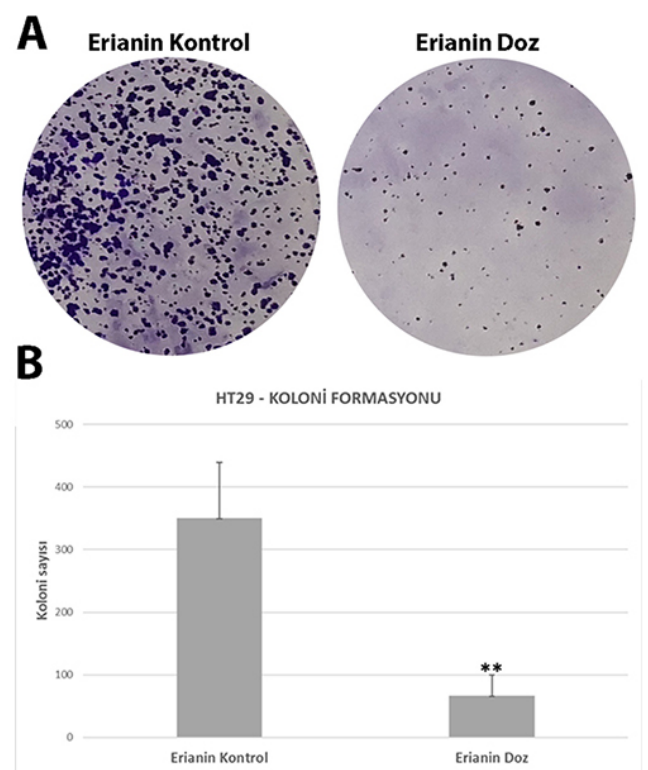

Şekil 2.

Erianin HT29 KRK hücrelerinde koloni oluşumu üzerine etkileri. A) Erianin ve kontrol gruplarinda kristal viyole ile boyanmış kolonilerin morfolojik görüntüsü. B) Erianin uygulanan grupta kontrol grubuyla kıyaslandı̆̆ında koloni sayısı anlamlı olarak azalmıştır $( \pm S S, n=3, p<0.01)$.

\section{Tartışma ve Sonuç}

Her y1l 1.2 milyondan fazla hastaya kolorektal kanser teşhisi konmakta ve 600.000'den fazla KRK hastası yaşamını yitirmektedir. Görülme sıklığı küresel olarak büyük ölçüde değişmekle birlikte insidansı erkeklerde kadınlardan daha yüksektir ve yaşla birlikte görülme sıklığı da $\operatorname{artmaktadır}^{18}$. Bu nedenle, KRK hastalarının prognozunu iyileştirmek için yeni ve güvenli tedavi stratejilerinin geliştirilmesine ihtiyaç vardır.

Doğal ürünler yeni antikanser ilaçlarının keşfinde verimli kaynaklar haline gelmiştir. Şu anda kullanılmakta olan antikanser ilaçlarının yaklaşık \%50'si doğrudan ya da dolaylı olarak doğal ürünlerden elde edilmektedir. Bu doğal ürünler; alkaloidler, polisakkaritler, polifenoller, diterpenoid ve doymamış yağ asitleri yapısındadırlar ${ }^{3}$. Kahverengi deniz yosunlarından elde edilen bir polisakkarit olan fucoidan'ın HT29 ve HCT116 hücrelerinde apoptozu indüklediğini gösterilmiştir ${ }^{3}$. Curcuma Longa'dan izole edilen bir polifenol olan Curcumin'in in vitro ve in vivo olarak, çoklu hücresel yolaklar yoluyla etki gösteren KRK'ya karş1 kanser önleyici özelliklere sahip olduğu gösterilmiştir ${ }^{19}$. Andrographolide bir diterpenoiddir ve Asya'da binlerce yıldır geleneksel bir bitkisel ilaç olarak kullanılan Andrographis paniculata bitkisinin başlıca biyoaktif bileşenidir ${ }^{3}$. Andrographolidin'in insan kolon kanseri hücrelerinde antiproliferatif ve apoptotik özellikleri gösterilmiştir ${ }^{20}$. Erianin, Dendrobium chrysotoxum'dan elde edilen anti-tümör ve anti- 
oksidan özelliklerinden dolayı tercih edilen doğal bir bibenzil bileşiğidir. Bizim çalışmamızın sonuçlarında doğal bir ürün olan erianinin KRK kanser hücrelerinde antikanserojen etkileri gösterilmiştir ve doğal ürünlerKRK kanser ilişkisini gösteren diğer çalışmaları destekler niteliktedir.

Son yıllarda, geleneksel Çin tıbbı alternatif tıp konusunda oldukça gelişme kaydetmiş ve birçok kanser türünde etkili tedavi sonuçları elde edilmiştir ${ }^{21,22}$. Farklı kanser hücrelerinde, doğal bileşiklerin aktif bileşenlerinin antikanserojen etkisinin ve altında yatan temel mekanizmaların aydınlatılması yeni anti-kanser ilaçların keşfinin önünü açacaktır. Bu amaçla erianinin antikanserojen etkisi çeşitli kanser türlerinde çalışılmıştır. Chen ve ark. Dendrobium özündeki yeni bir dibenzil bileşiği olan erianinin kalsiyum/kalmodülin aracılı ferroptoz yoluyla akciğer kanseri hücre büyümesini ve göçünü inhibe ettiğini göstermiştir ${ }^{14}$. Zhu ve ark. erianinin mitokondriyal apoptoz ve JNK yolakları yoluyla mesane kanseri hücresi büyümesini inhibe ettiğini ve mesane kanseri tedavisi için ümit veren bir terapi bileşiği olabileceğini önermiştir. Diğer bir çalışmada, erianinin insan nazofarengeal karsinomunda ERK yoluyla hücre apoptozunu indüklediği ve nazofarengeal kanser terapisi için umut vaat eden doğal bir bileşik olabileceği bildirilmiştir ${ }^{21}$. Ancak, erianinin HT29 kolon kanseri hücrelerinin canlılığı ve koloni oluşumu üzerine etkileri bilinmemektedir. $\mathrm{Bu}$ çalışmada, erianinin HT29 KRK hücrelerinin proliferasyonu ve koloni oluşumu üzerine etkileri ilk kez araşt1rılmıştır.

Erianinin kolorektal kanser hücre canlılığ1 üzerindeki etkilerini belirlemek için HT29 hücre hattı kullanılmıştır. Bizim çalışmamızda erianinin HT29 hücrelerinde doz ve zaman bağımlı olarak sitotoksik etki gösterdiği XTT metodu ile belirlenmiştir. Erianinin IC $_{50}$ dozu 48'inci saatte HT29 hücrelerinde $59.05 \mu \mathrm{M}$ olarak belirlenmiştir. Sun ve ark. erianinin T47D hücrelerinde hücre proliferasyonunu azalttığını göstermiştir $^{15}$. Diğer bir çalışmada, erianinin insan servikal kanser hücrelerinde antiproliferatif etkisi gösterilmiştir $^{11}$. Aynı zamanda, erianinin osteosarkoma hücre proliferasyonunu baskıladığı da bildirilmiştir ${ }^{13}$.

In vitro koloni oluşturan analizler, kanser tedavilerinin sonucunu tahmin etmek için kullanılabilir ve genellikle antikanser ilaçları test etmek için kullanılır ${ }^{23}$. Sunulan çalışmada, erianinin HT29 KRK hücrelerinin koloni oluşumu üzerine etkileri koloni formasyonu analizi ile değerlendirilmiştir. Bizim sonuçlarımız, erianinin HT29 KRK hücrelerinde kontrol grubuyla kiyaslandığında koloni oluşumunu anlamlı olarak azalttığı$\mathrm{n}$ göstermiştir.

Sonuç olarak, biyoaktif bileşikler, yeni ajanlar ve biyomarkır moleküller kanser tedavisinde in vivo ve in vitro çalışmalarda araştırılmıştır. Bu tümörlerin onkogenezisinin ve altında yatan temel mekanizmaların aydınlatılması yeni kanser terapilerin geliştirilmesinin önünü açacaktır. Bu nedenle kolorektal kanser terapisinde yeni biyolojik ve kimyasal reaktiflere ihtiyaç artmaktadır. Bizim sonuçlarımız erianinin HT29 KRK hücre proliferasyonunu ve koloni oluşumunu anlamlı olarak azalttığını göstermiştir. Erianin, kolorektal kanser terapisi için tek başına ya da diğer moleküllerle kombine olarak bir aday olabilir. Gelecekte erianinin kolorektal kanser hücreleri üzerindeki etki mekanizmasını aydınlatacak daha kapsamlı ve çok merkezli desteklenecek ileri düzeyde klinik çalışmalara ihtiyaç vardir.

\section{Etik Kurul Onay Bilgisi:}

Bu çalışma etik onam alınması gereken çalıșmalar kapsamı dışında olan hücre kültürü çalışmasıdır ve 01.06.2020-01.10.2020 tarihleri arasında gerçekleştirilmiş̧ir.

\section{Araştırmacı Katkı Beyanı:}

Fikir ve tasarım: S.S.K., M.S., L.E.; Veri toplama ve ișleme: L.E., M.S.; Analiz ve verilerin yorumlanması: S.S.K., M.S.; Makalenin önemli bölümlerinin yazılması: S.S.K.

Destek ve Teşekkür Beyanı: Çalışmaya yönelik yaptığı düzenleme katkısından dolayı Öğretim Görevlisi Ercan Koçoğlu'na teşekkür ederiz.

\section{Çıkar Çatışması Beyanı:}

Makale yazarının çıkar çatışması beyanı yoktur.

\section{Kaynaklar}

1. An BC, Hong S, Park HJ, vd. Anti-Colorectal Cancer Effects of Probiotic-Derived p8 Protein. Genes 2019; 10(8). doi:10.3390/genes10080624

2. Weng W, Goel A. Curcumin and colorectal cancer: An update and current perspective on this natural medicine. Seminars in Cancer Biology 2020. doi:10.1016/j.semcancer.2020.02.011

3. Huang X mei, Yang Z jie, Xie Q, Zhang Z kang, Zhang H, Ma $\mathrm{J}$ ying. Natural products for treating colorectal cancer: A mechanistic review. Biomedicine and Pharmacotherapy 2019; 117: 109142. doi:10.1016/j.biopha.2019.109142

4. Chung SS, Dutta P, Chard N, vd. A novel curcumin analog inhibits canonical and non-canonical functions of telomerase through STAT3 and NF- $\mathrm{B}$ inactivation in colorectal cancer cells. Oncotarget 2019; 10(44): 4516-4531. doi:10.18632/ oncotarget. 27000

5. Gamage CDB, Park SY, Yang Y, vd. Deoxypodophyllotoxin exerts anti-cancer effects on colorectal cancer cells through induction of apoptosis and suppression of tumorigenesis. International Journal of Molecular Sciences 2019; 20(11): 2612. doi:10.3390/ijms20112612

6. Wang S, Wang L, Zhou Z, vd. Leucovorin Enhances the Anticancer Effect of Bortezomib in Colorectal Cancer Cells. Scientific Reports 2017; 7(1): 682 doi:10.1038/s41598-01700839-9

7. Wang $\mathrm{X}, \mathrm{Li}$ T. Ropivacaine inhibits the proliferation and migration of colorectal cancer cells through ITGB1. Bioengineered 2021; 12(1): 44-53. doi: 10.1080/21655979. 2020.1857120

8. Hlosrichok A, Sumkhemthong S, Sritularak B, Chanvorachote P, Chaotham C. A bibenzyl from Dendrobium ellipsophyllum induces apoptosis in human lung cancer cells. Journal of Natural Medicines 2018; 72(3): 615-625. doi:10.1007/s11418018-1186-X 


\section{Erianinin HT29 hücreleri üzerine etkileri}

9. Guo Z, Zhou Y, Yang J, Shao X. Dendrobium candidum extract inhibits proliferation and induces apoptosis of liver cancer cells by inactivating $\mathrm{Wnt} / \beta$-catenin signaling pathway. Biomedicine and Pharmacotherapy 2019; 110: 371-379. doi: 10.1016/j.biopha.2018.11.149

10. Yang L, Hu Y, Zhou G, Chen Q, Song Z. Erianin suppresses hepatocellular carcinoma cells through down-regulation of PI3K/AKT, p38 and ERK MAPK signaling pathways. Bioscience reports 2020; 40(7): BSR20193137. doi:10.1042/BSR20193137

11. Li M, He Y, Peng C, Xie X, Hu G. Erianin inhibits human cervical cancer cell through regulation of tumor protein p53 via the extracellular signal-regulated kinase signaling pathway. Oncology Letters 2018; 16(4): 5006-5012. doi:10.3892/ol.2018.9267

12. Zhu Q, Sheng Y, Li W, vd. Erianin, a novel dibenzyl compound in Dendrobium extract, inhibits bladder cancer cell growth via the mitochondrial apoptosis and JNK pathways. Toxicology and Applied Pharmacology 2019; 371: 41-54. doi:10.1016/j.taap.2019.03.027

13. Wang H, Zhang T, Sun W, vd. Erianin induces G2/M-phase arrest, apoptosis, and autophagy via the ROS/JNK signaling pathway in human osteosarcoma cells in vitro and in vivo. Cell Death and Disease 2016; 7(6): e2247. doi:10.1038/cddis.2016.138

14. Chen P, Wu Q, Feng J, vd. Erianin, a novel dibenzyl compound in Dendrobium extract, inhibits lung cancer cell growth and migration via calcium/calmodulin-dependent ferroptosis. Signal Transduction and Targeted Therapy. 2020; 5(1): 51. doi:10.1038/s41392-020-0149-3

15. Sun J, Fu X, Wang Y, vd. Erianin inhibits the proliferation of T47D cells by inhibiting cell cycles, inducing apoptosis and suppressing migration. American journal of translational research. 2016;8(7):3077-3086.
16. Rajendran V, Jain MV. In vitro tumorigenic assay: colony forming assay for cancer stem cells. Içinde: Methods in Molecular Biology 2018; 1692: 89-95. doi:10.1007/978-14939-7401-6_8

17. Franken NAP, Rodermond HM, Stap J, Haveman J, van Bree C. Clonogenic assay of cells in vitro. Nature Protocols 2006; 1(5): 2315-2319. doi:10.1038/nprot.2006.339

18. Brenner H, Kloor M, Pox CP. Colorectal cancer. The Lancet 2014; 383: 1490-1502. doi:10.1016/S0140-6736(13)61649-9

19. Ruiz de Porras V, Layos L, Martínez-Balibrea E. Curcumin: A therapeutic strategy for colorectal cancer? Seminars in Cancer Biology 2021; 73: 321-330. doi:10.1016/j. semcancer. 2020.09.004

20. Khan I, Mahfooz S, Ansari IA. Antiproliferative and Apoptotic Properties of Andrographolide Against Human Colon Cancer DLD1 Cell Line. Endocrine, Metabolic \& Immune Disorders Drug Targets 2019; 20(6): 930-942. doi: 10.2174/1871530319666191125111920

21. Liu YT, Hsieh MJ, Lin JT, vd. Erianin induces cell apoptosis through ERK pathway in human nasopharyngeal carcinoma. Biomedicine and Pharmacotherapy 2019; 111: 262-269. doi:10.1016/j.biopha.2018.12.081

22. Zhu Q, Sheng Y, Li W, vd. Erianin, a novel dibenzyl compound in Dendrobium extract, inhibits bladder cancer cell growth via the mitochondrial apoptosis and JNK pathways. Toxicology and Applied Pharmacology 2019; 371: 41-54. doi:10.1016/j.taap.2019.03.027

23. Cho JG, Lim KH, Park SG. MED28 increases the colonyforming ability of breast cancer cells by stabilizing the ZNF224 protein upon DNA damage. Oncology Letters 2018; 15(3): 3147-3154. doi:10.3892/ol.2017.7718 
